\title{
An e-Business Class Using Just-in-Time Teaching and Cooperative Learning with a Constructivist Approach
}

\author{
Nina McGarry and Mary J. Granger \\ George Washington University, Washington, DC USA
}

nmcgarrv@gwu.edu granger@gwu.edu

\begin{abstract}
This paper reviews the inventiveness of faculty combined with the resources of the World-Wide-Web in creating a just-in-time course for seniors studying e-Business. Additionally, the instructor incorporated cooperative learning adhering to a constructivist teaching approach. Adherence to just-in-time teaching using cooperative learning following a constructivist approach supports the goals of rapid access to the latest information, exchange of ideas and evolution of new concepts. It was an opportunity to develop a real project, incorporating meaningful skills learned in other business disciplines, with the potential for enhancing their future careers. This course is an exposure to searching for and using the most current and vital information necessary to thrive in the changing situations. It also enables students to learn how to learn.
\end{abstract}

Keywords: JiTT (Just in Time Teaching), Cooperative Learning, Constructivist Approach.

\section{Introduction}

This paper reviews the inventiveness of faculty combined with the resources of the World-Wide-Web in creating a just-in-time course for seniors studying e-Business. Additionally, the instructor incorporated cooperative learning adhering to a constructivist teaching approach. This paper briefly reviews just-intime teaching, cooperative learning and constructivist approach and the integration of these three teaching strategies to an e-Business course. The experience gained from business education adapting to these strategies may set a new path for future business school education. Several lessons learned from the experience will ensure more effective teaching and learning knowledge in future classes when these strategies are implemented.

Interest for using these course methodologies stem from the rapidly changing world of technology. Structuring an e-Business course responsive to a changing environment almost precludes use of a textbook. The class structure suggested a strategy in which evolving information and concepts are reviewed with existing literature and proven standards to determine an applicable solution. The course focused on utilizing student knowledge and experience as well as forming new knowledge. Adherence to just-in-time teaching using cooperative learning following a constructivist approach supported the goals of rapid access to the latest information, exchange of ideas and evolution of new concepts.

Material published as part of these proceedings, either on-line or in print, is copyrighted by Informing Science. Permission to make digital or paper copy of part or all of these works for personal or classroom use is granted without fee provided that the copies are not made or distributed for profit or commercial advantage AND that copies 1) bear this notice in full and 2) give the full citation on the first page. It is permissible to abstract these works so long as credit is given. To copy in all other cases or to republish or to post on a server or to redistribute to lists requires specific permission from the publisher at publister@intormingscience.org

\section{Constructivist Approach to Teaching}

The constructivist approach to education moves away from the traditional, didactic teaching processing of the past. No longer are students engaged in a 'sit-and-listen' approach to instruction. In the constructivist approach, education becomes stu- 
dent-focused based on exploration and experimentation. This approach allows students to explore ideas and construct knowledge based on their own observations and experiences. In short, constructivism is characterized as a "a philosophical approach to teaching rather than a given set of particular practices" and is "an active process for students" (Smerdon, Burkham and Lee 1999). A constructivist approach is an "active process in which learners construct new ideas or concepts based upon their current/past knowledge" (Bruner 1966).

Therefore, a constructivist approach to teaching rests on several assumptions:

(1) "what constitutes "knowledge" may be culturally constructed, rather than truth or fact;

(2) knowledge is distributed among group members and the knowledge of the group is greater than the sum of the knowledge of individuals; and

(3) learning is an active, rather than passive, process of knowledge construction" (Smerdon, Burkham, and Lee 1999).

These assumptions support Vygotsky's (1986) idea that "one of the principle limitations of the method of definition lies in its abstraction from the real processes of problem solving confronting ... everyday life." Vygotsky argued that didactic learning, or providing definitions that the student commits to memory, ignores the fluidity of the development process. In the development process, perception and mental elaboration are an active part of the intellectual process, constantly engaged in serving communication, understanding, and problem solving. This theory is further supported by Bruner (1966) whereby he posits that "a theory of instruction should address four major aspects:

(1) predisposition towards learning,

(2) the ways in which a body of knowledge can be structured so that it can be most readily grasped by the learner,

(3) the most effective sequences in which to present material, and

(4) the nature and pacing of rewards and punishments."

Bruner expands this theoretical framework in later work $(1986,1990)$ encompassing social and cultural influences of learning.

So far, the concept of learner focused approach, learning theory, is presented. However, another aspect addresses epistemology - how people learn and the nature of knowledge. As Hein states "if we accept constructivist theory (which means we are willing to follow in the path of Dewey, Piaget and Vigotsky among others), then we have to give up Platonic and all subsequent realistic views of epistemology" (Hein 1991). Hein argues that this suggests knowledge does not exist except for that which we ourselves construct from experiences. He further stipulates that this is dangerous. This construction of knowledge is dangerous because "we believe that knowledge consists of learning about the real world out there". As such, as educators, we "organize it in the most rational way possible" and "present it to the learner" (Hein 1991). Hein states that a constructivist approach requires the learner to "construct his or her own world" (Hein 1991).

In summary, Hein agrees with the concept of constructivist instruction but insists that it is not enough. Hein supports Vygotsky's "zone of proximal development" which is finding the correct level of instruction for the learner. 'Zone of proximal development' argues that learners need to stretch beyond their comfort area with the support and guidance of an expert.

Adhering to a constructivist approach requires the instructor be well versed in the topic. The instructor must anticipate or see connections to issues raised by learners and offer some structure to course content. 


\section{Cooperative Learning}

"Skills that will make the U.S. work force more productive and U.S. organizations more competitive in the global marketplace" are based on "the ability to work cooperatively" (Young, Bormann and Henquinet 2000). This ability to work cooperatively is a result of the continual decentralization of decisionmaking in organizations coupled with a complex work environment requiring more interaction among employees. As frequently as humans are referred to as 'social animals' the skill of working in teams requires nurturing and development. Cooperative learning nurtures and develops team-based interaction.

Typically, cooperative learning involves arranging opportunities for small teams of students to work together to master material and demonstrate competency. More specifically, students demonstrate positive interdependence in creating a single product with individual accountability also expected. (Morgan, Whorton and Gunsalus 2000).

The technique of cooperative learning within teams is pervasive in education circles is used at all instructional levels (Felder and Brent 1994; Sologok, Stamen and Vetter 2001; Van Meter and Stevens 2000; Young, Bormann and Henquinet 2000). Instructors in all educational situations are extremely satisfied with this learning technique.

These reports of high satisfaction are a result of recognizing that "pervasive, lasting cognitive change requires time" (Van Meter and Stevens 2000). Using cooperative learning in chemical engineering instruction, Felder and Brent (1994) found students working in teams to accomplish a goal retained the knowledge longer and scored higher on exams than those students participating in a traditional dyadic instructional process. Felder and Brent adopted Johnson, Johnson and Holubec's (1993) conditions of:

1) positive interdependence

2) individual accountability

3) face-to-face interaction

4) appropriate use of collaborative skills and

5) group processing.

These activities may occur either in class or outside of class. Length of in-class exercises range upward from thirty seconds. Timeframes are dependent on the exercise and intent of instruction. In order to understand a variety of learning styles and problem solving methods, it is also recommended that team membership change throughout the course experience. The activity of changing team membership, supporting learning with an instructor as coach, produces higher level critical analysis and reasoning skills, a deeper understanding of the material and lower levels of anxiety (Felder and Brent 1994).

Individual accountability is considered necessary to ensure that students share the workload with the less industrious students providing the same level of support as more industrious students. For this reason, it is recommended that team composition alter throughout the semester with team members identifying individual contributions to the task.

Cooperative learning is active learning. It clearly compliments the use of brainstorming, small team activities and case study exercises. Bruner (1986) provides many examples for creating teams within an academic setting.

\section{Just in Time Teaching (JiTT)}

Just-in-time teaching (JiTT) is a strategy focusing on creating immediate learning opportunities for students. Similar to its predecessors in the manufacturing world, JiTT strategies involve providing current information to the student or the student retrieving the facts.. Accessing up-to-date information often re- 
quires access to the World Wide Web. At least, the students perceive this method as the easiest path to retrieving this information.

Some instructors may use JiTT in the actual classroom to enhance the learning experience as demonstrated by the US Air Force Academy in teaching physics

(http://www.usafa.af.mil/dfp/physics/webphysics/usafajitt). The instructor of the e-Business course implemented JiTT in a less structured environment. Initially, articles, published and accessible on the Web several months before the start of the semester, were collated. Once the semester began, students were responsible for collecting more recent articles focusing on the weekly topic. In order to obtain the most current information, students were encouraged to use Web resources. These articles were shared with the rest of the students, either through a web-based course management tool or paper copies during class time.

In order to guide and focus the just-in-time experience, questions or suggestions for each discussion topic are posted in the web-based course management tool. Just-in-Time Teaching is a new phenomenon. It takes advantage of the availability of the World Wide Web for finding material, in class or in preparation for class. A recent research example reports on JiTT used to teach Physics classes by Andrew Gavin, Professor of Physics, Indiana University - Purdue Univesity at Indiana and at the US Air Force Academy http://www.pkal.org/. However, the concept of JiTT is applicable to any subject area where data is changing and changing rapidly.

\section{The e-Business Class}

The main components of the class are: weekly reading teams, e-Business development teams, and class participation. As suggested (Felder and Brent 1994) there were two different sets of teams formed. The teams involved with the e-Business development were selected by the instructor; the students self-selected teams for the weekly reading assignments.

Each week one team was responsible for leading the discussion for the designated topic. All student teams, even those not leading the discussion, were required to read the instructor-provided relevant articles, review the questions and critique the articles addressing the questions. All critiques from each team were posted to the course management tool at least 12 hours prior to class. In order to prepare for the inclass discussions, all students read the weekly article critiques. The session reading team is identified as the lead reading team and was responsible for: leading discussions on articles from the instructordeveloped text, providing additional current articles relating to the session topic, bridging discussion between the instructor-provided articles and the current articles; respond to critiques from other teams. At times, the instructor clarified issues, provided additional material or kept the discussion focused. Each week produced very lively discussions enhanced with student experiences and difference of opinions.

In order to ensure an even composition of gender and disciplines, the instructor created teams for the eBusiness development project. On the first day of class, students completed a brief survey identifying their age, sex, field of study and experience level with web development software. The instructor allocated team membership on web development software skill level first and subsequently by field of study, then age and finally sex. This evolution tried to provide a wide breadth of capabilities, experience and diversity on each team.

The second course component, the e-Business development task, is identifying, researching and proposing an e-Business. Each team presented preliminary findings incorporating the applicability of previous session topics to their e-Business ideas. These presentations were followed by five minutes of questions and answers. Classmates were the venture capitalists reviewing new e-Business possibilities with \$2 million 'monoply' money to invest across the e-Business ideas. Classmates anonymously completed a brief evaluation of each e-Business, excluding their own team. The students answered the following question for each team: 
What is the company name?

What does the company do?

Would you invest in this company, why or why not?

How much would you invest in this company?

What type and frequency of reports would you request?

All comments were posted to the web-based course management software for review by students.

At the end of the semester, there will be a re-evaluation of the e-Business ideas encompassing market analysis, technology assessment, and human computer interaction. The students will determine what percentage of their investment dollars to commit to each of the e-Businesses. Students will assess each team's presentation abilities, ability to respond to questions, market research, technology feasibility, and human computer interaction design of web site. Additionally, a comprehensive company concept paper will be posted on the course management tool. Other instructors from the business school will participate in the final evaluation of the e-Businesses.

The third component is class participation. Class participation consisted of participation in the weekly topic discussions and interaction with other students. Class attendance at each session was extremely high. On average, class attendance at each session was $98 \%$.

\section{Lessons Learned}

While the experience from conducting a course in this fashion was frightening at first, it evolved into a genuinely rewarding experience. Some of the lessons learned involve the use of a textbook, which, as soon as it is published is almost out of date and fails to incorporate evolving materials. While the idea of up-to-date (3-4 month old) articles kept the instructor-provided articles relevant, the expense to students and the time involved to find and reproduce the materials is steep. The final cost, with copyright privileges, proved to be as expensive as a printed text and adopting an existing textbook is a very real possibility for future course offerings. Therefore, one recommendation is to find a suitable textbook. However, to keep the course just-in-time, there still needs to be identification of current articles to supplement the textbook. As another option, the instructor might just provide the web locations for the materials and thereby making the students responsible for locating the readings. In either case, in order to remain upto-date, many of the articles used this semester will have to be replaced. Additionally, the students will find additional information for the weekly discussions.

All teams will identify each team member's contribution to the activities. The limited enrollment in the course enabled each team to lead the weekly discussion several times and there is a perception that the reading teams became disenchanted with their members towards the conclusion of the semester. In order to prevent dissatisfaction with team members, perhaps team composition should be changed after each team had the opportunity to lead a discussion. This team rotation depends upon the size of the class and the number of students on a team.

The e-Business project will be retained for future course offerings. Based on the final presentations, there may be some adjustments in either the specifications or the requirements. It is an opportunity to develop a real project, incorporating meaningful skills learned in other business disciplines, with the potential for enhancing their future careers.

\section{The e-Business Experience - Summary}

The semester ends in several weeks. The final outcomes can be incorporated in either the final submission or the conference presentation. However, comments from students, and attendance levels demonstrate, an enthusiasm for the course. The exposure to new information and reactions of their peers pro- 
duces a collaborative learning environment in what a simulation enthusiast (Adams, 1973) identifies in three steps of:

"1) an understanding of the structures of knowledge

2) connecting subject matter (cognitive) and emotional (affective) learning; and

3) an appreciation of team dynamics."

The experience has combined constructivist theory by enabling the students to build their knowledge based on experience in a cooperative environment of team experiences with a just-in-time teaching approach that adjusts educational strategies. The instructor must be prepared in the subject matter to facilitate learning in a feedback type of loop implemented by student's preparation and influences outside of the classroom that subsequently enter the classroom. This response strategy is the strength of the constructivist approach to education.

It is felt, that even with the demise of numerous e-Businesses, many are going to survive and many will be newly developed. However, those responsible must be able to respond to the evolving environments. This course is an exposure to searching for and using the most current and vital information necessary to thrive in the changing situations. It also enabled students to learn how to learn.

\section{References}

Adams, Dennis M. Simulation Games: An Approach to Learning. (1973) Charles A. Jones Publishing Company. Worthington, $\mathrm{OH}$

Bruffee, Kenneth A. Collaborative Learning: Higher Education, Interdependence and the Authority of Knowledge. (1993) Johns Hopkins University Press.

Bruner, J. (1960). The Process of Education. Cambridge, MA: Harvard University Press.

Bruner, J. (1966). Toward a Theory of Instruction. Cambridge, MA: Harvard University Press.

Bruner, J. (1986). Actual Minds, Possible Worlds. Cambridge, MA: Harvard University Press.

Bruner, J. (1990). Acts of Meaning. Cambridge, MA: Harvard University Press.

Bruner, J., Goodnow, J., \& Austin, A. (1956). A Study of Thinking. New York: Wiley.

Christensen, Edward W. and James R. Bailey. (2000) "Repository Choice: An Exploration of Accessibility, Satisfaction and Usefulness". Proceedings of the $33^{\text {rd }}$ Hawaii International Conference on System Sciences.

Felder, Richard M. and Rebecca Bent (1994) "Cooperative4 Learning in Technical Courses: Procedures, Pitfalls, and Payoffs". ERIC Document Reproduction Service Report ED 377038 .

Hein, George E. (1991) “Constructivist Learning Theory”. International Committee of Museum Educators Conference. October.

Johnson, D.W., Johnson, R.T., and Holubec, E.J. (1993) Cooperation in the Classroom. (6th ed.). Edina, MN: Interaction Books.

Morgan, Robert L., James E. Whorton and Cynthia Gunsalus. (2000) "A Comparison of Short Term and Long Term Retention Lecture Combined with Discussion Versus Cooperative Learning”. Journal of Instructional Psychology. 27(1) pp.53-8.

Smerdon, Becky A.; David T. Burkam and Valerie E. Lee. (1999) “Access to Constructivist and Didactic Teaching: Who Gets It? Where Is It Practiced?”. Teachers College Record 101(1) pp. 5-34.

Sologuk, Sally, Ronald Stammen, and Ronald Vetter. (2001) "A Collaborative Approach for Creating Curriculum and Instructional Materials". Journal of Technology and Teacher Education. Vol 9(2), pp.199-210.

Van Meter, Peggy and Robert J. Stevens. (2000) “The Role of Theory in the Study of Peer Collaboration". The Journal of Experimental Education 69(1). pp.113-27.

Vygotsky, Lev.(2000) Thought and Language. MIT Press. (12 ${ }^{\text {th }}$ printing). 
McGarry\& Granger

Young, Carol Bormann and Janet A. Henquinet. (2000) “A Conceptual Framework for Designing Group Project”. Journal of Education for Business. 76(1), pp.56-60. 